Radiation Risks and Radionuclide Contamination

\title{
Ecological and Radiological Situation in the Stavropol Territory
}

\author{
Nataliya Lagutina, Leonid Neupokoev, Alexander Novikov, Anatoly Pukhovsky, Olga Sumarukova \\ Russian State Agrarian University - Moscow Timiryazev Agricultural Academy, Institute of Amelioration, \\ Water Management and Construction named after A.N. Kostyakov, 127550, Moscow, Russia
}

doi: https://doi.org/10.21467/abstracts.93.84

\section{ABS T RA C T}

The average effective radiation doses for the population of the Stavropol Territory do not differ significantly from the average radiation levels for population produced by natural, medical and technogenic ionizing radiation sources (IRS), as well as global fallout registered over the past 5 years. Dynamics of these indicators shows no significant changes in the recent years. The results of radiation-hygienic certification indicate that doses from natural $(93.53 \%)$ and medical (6.37\%) sources take the lead in the structure of collective radiation doses for population of the Stavropol Territory.

There are no zones of global radiation pollution (of technogenic nature as a result of radiation accidents) in the Stavropol Territory. No local pollution sites have been registered in recent years. However, radiological studies in the open areas of the Predgorny district show natural radiation anomalies associated with uranium ore occurrences, as well as technogenic radioactive contamination sites (RCS) of the past years due to the activities of uranium ore mining enterprise. Scientific Production Association "Almaz" (Lermontov) has stopped mining and processing uranium ore, but the rehabilitation of contaminated areas after its activities is not completed yet.

As a part of socio-hygienic monitoring, radiation safety was controlled based on gamma radiation dose rates in open areas, determination of total alpha and beta activity in drinking water, determination of technogenic radionuclides in food, soil and open water bodies. Proportion of water samples exceeding the control levels for total alpha-beta activity and (or) intervention levels (IL) of individual radionuclides is less than $2 \%$. Fluctuations of total alpha activity in underground water sources were noted as seasonal variations. Radiation doses for the population due to consumption of drinking water do not exceed $0.1 \mathrm{mSv} /$ year.

Natural ionizing radiation sources are leading radiation factors for the population of the Stavropol Territory. The contribution of natural ionizing radiation sources to collective radiation dose makes $91.65 \%$. Based on data from radiation-hygienic certification and Unified Control System for Individual Radiation Doses (UCSID) it was found that the average individual annual dose in the Territory, taking into account the effects of all sources, was $3.01 \mathrm{mSv} /$ year, of which $2.64 \mathrm{mSv} /$ year came from natural ionizing radiation sources. Radiation dose rates for population vary within the levels registered during long-term observations in the region.

According to radiation-hygienic monitoring data, external radiation dose rates in open areas were from 0.09 to $0.21 \mathrm{mSv} /$ year, which corresponds to background values in the Territory. In order to assess the sanitary and epidemiological situation at high-risk facilities, annual laboratory tests were organized to check radiation safety indicators of soil at the monitored points. Analysis of the annual radiation-hygienic certification results for the Stavropol Territory and maintenance of the regional database of radiation doses for population allows objectively assessing the contribution of natural ionizing radiation sources to formation of collective radiation doses. Uneven content of natural uranium-thorium radionuclides in the underlying soils forms radon-hazardous sites and zones. It should be noted that all radon-hazardous sites are located in the Caucasian Mineral Waters area and are local. This area belongs to regions with increased radiation doses

(C) 2020 Copyright held by the author(s). Published by AIJR Publisher in "Abstracts of The Second Eurasian RISK-2020 Conference and Symposium" April 12- 19, 2020, Tbilisi, Georgia. Jointly organized by AMIR Technical Services LLC, Georgian Technical University, Institute of Geography (Kazakhstan) and Russian Institute of Petroleum Geology and Geophysics.

AijR DOI: $10.21467 /$ abstracts.93 
The Second Eurasian RISK-2020 Conference and Symposium

(above $5 \mathrm{mSv} /$ year). Radon isotopes and decay products account for more than half of formed effective radiation doses. Enterprises and institutions operating ionizing radiation sources under normal conditions contribute by no more than $0.1 \%$ to formation of total collective radiation dose for the population.

According to the North Caucasus Inspection Department for Radiation Hazardous Facilities of the Don Interregional Territorial Administration for Nuclear and Radiation Safety Supervision at the Federal Service for Ecological, Technological and Atomic Supervision, 23 organizations having 55 radiation facilities operate in the Stavropol Territory under the supervision of the Department. Radiation safety at atomic energy facilities during operation of radiation sources and handling of radioactive substances, products based on them and radioactive waste is ensured by: creating conditions for safe work with ionizing radiation sources; organizational activities; building an accounting and control system for radioactive substances and radioactive waste, which excludes the possibility of their uncontrolled use or theft; training managers and specialists for organizations responsible for radiation safety; instructing personnel that operates radiation sources on safe practices and working methods; willingness of organizations to eliminate the consequences of possible radiation accidents; creating radioactive waste management system; physical protection of radiation sources, radioactive substances and their storage places.

Based on the inspection results it was found that radiation safety conditions in the supervised organizations is satisfactory (the noted violations of license requirements and Federal Standards and Rules for Atomic Energy Use did not cause any harm to human health or the environment). 